\title{
Christmas quiz
}

1. (a) Did Mendel have to cheat to discover the fundamental laws of genetics? years?

(b) Why were his results not recognised for forty

2. Norbert Wiener, Julian Schwinger, James Watson and Murray Gell-Mann were all child prodigies. But which was the most prodigious?

3. James Sumner and John Cornforth both obtained Nobel prizes for chemistry, albeit 29 years apart. What else did they have in common?

4. A question for women's year: The female is often larger as well as more deadly than the male. In which species is the imbalance greatest?

5. In which film, made in 1944, was there a sub-plot of German agents trying to smuggle uranium out of America?

6. In which book:

(a) was there a submarine powered by the same force as powers the Sun (written 1870);

(b) did Japan launch a surprise aerial attack on the west coast of America (written 1908);

(c) did scientists develop strains for biological warfare (and subsequently use them on China, the emergent world power) (written 1914);

(d) did a group of 'conservationists' fight the profligate squandering of natural resources by big business (written 1952)?

7. Whose correspondence was found recently in the Old and New Worlds, and what was the subject discussed?
8. For they have sown the wind, and they shall reap the reward. When was this biblical warning renewed recently, and what human activity was said to be the cause?

9. Which animal with ecclesiastical connections may aid investigations of human demyelinating disease?

10. What was the first anorectic drug used in the treatment of obesity?

11. What effect is season of birth supposed to have on the incidence of schizophrenia?

12. When was the first purely scientific journal founded?

13. Who's got arms coming out of his head?

14. Who invented the linear motor and ran away from the Royal Institution?

15. Who began by counting from 1 to 10 in binary form, added on the atomic numbers of hydrogen, carbon, nitrogen, oxygen and phosphorus, then twice 4,000 , and drew a cuboid biped 14 wavelengths high with a helix on its head? And who turned it upside down?

16. In spite of the demise of flower children, strings of beads are still in favour with one group. Who are they?

17. Who said:

(a) Science is the cemetery of dead ideas;

(b) Science is the topography of ignorance;

(c) Science is nothing but perception;

(d) Science is the great antidote to the poison of enthusiasm and superstition?

See page 556 for answers.

\section{Miscellaneous intelligence}

- "Contrary to the trends in all other countries in the European Economic Community the rate of movement into human consumption in Great Britain increased during the three previous seasons (and shows a provisional offtake for $1974 / 75$ of $222 \mathrm{lb}$ per head per annum)." So says the Potato Marketing Board in its latest annual report, meaning that although the British people had been eating more potatoes during the past few years, they now seem to be eating fewer. Does this indicate that they might be in a spud-deficient situation?

Oh for the elegant style of yesteryear. Lecturing at Gresham College, London on October 26, 1681, John Flamsteed, first Astronomer Royal, warned: "Hee that has not a Competent understanding in Geometrie, a thorough knowledge of plaine \& sphericall Trigonometrie, with the Severall Theoryes of the planets motions, hee that with these is not well acquainted with the Sphere it selfe, \& its severall projections \& knowes not readily the Constellations, ought not to pretend to the businesse in which all these are required..." For further enjoiement, even if you knowe not one end of a telescope from ye other, see ye full texte in The Gresham Lectures of John Flamsteed, edited by E. G. Forbes (Mansell, London, 1975).
A recent joint meeting of the Society of Chemical Industry and the Society for Occupational Medicine heard the momentous news that dialogue between the professions of chemistry and medicine was difficult in that each tended to use its exclusive jargon.

Elsevier has published yet another journal. Mass Emergencies is intended for everybody concerned with problems of emergencies and disasters. It is to be hoped that it soon tells them what to do about an avalanche of new journals.

A new book from Oxford University Press has a chapter-Education: how to make the best use of your brain-which might have been the answer to many a prayer. Sadly for aspiring geniuses, it describes no tricks for improving the power of mind over matter. Keeping to the realms of the possible, it deals largely with the acquisition of human skills. (Explaining the Brain is by Ritchie Russell with A. J. Dewar.)

Television talks for small planters have been delivered by the staff of the Mauritius Sugar Industry Research Institute, according to the institute's latest annual report. Bad luck tall planters. 


\section{Announcements}

\section{Award}

The Belgian Academy of Medicine has awarded the Pfizer Prize 1972-1973 to Professor Jacques E. Dumont of the Institute of Interdisciplinary Research, School of Medicine, University of Brussels.

\section{Appointments}

Dr Arturo Gomez-Pompa has been elected chairman of the International Co-ordinating Council of UNESCO's Man and the Biosphere Programme.

Dr Frank Read has been made a Professor in the Department of Physics at the University of Manchester.

Professor Sela has been inaugurated as president of the Weizman Institute.

\section{International meetings}

January 28-29, The northern great barrier reef, London (The Royal Society, 6 Carlton House Terrace, London SW1Y 5AG, UK).

February 2-6, Nuclear techniques in animal production and health as related to the soil-plant system, Vienna $(H$. D. Hamel, Joint FAO/IAEA Division of Atomic Energy in Food and Agricul-

\section{Answers to Christmas quiz}

1. (a) Not necessarily (see Nature, 256, 206; 1975).

(b) Nägeli the botanist and other naturalists failed to recognise their importance; Mendel became involved with administration on his appointment as abbot of his monastery, and as his girth expanded Mendel found it increasingly difficult to reach his pea plants (especially the short breed).

2. Norbert Wiener entered college at the age of 11 and gained his $\mathrm{PhD}$ at 18 . The others were retarded to the extent of only starting college at 14/15 and not obtaining their doctorates until $21 / 22$.

3. Both had to overcome a severe physical handicap. Sumner had his left arm amputated as a teenager. Cornforth has been completely deaf from birth.

4. The female deep sea angler fish can be 500,000 times heavier than the male.

5. Notorious, directed by Alfred Hitchcock. Professor R. A. Millikan told him that the whole idea of an atomic bomb was ridiculous, but the FBI still kept Hitchcock under surveillance for 3 months. ture, Kärntner Ring 11, P.O. Box 590, A-1011 Vienna, Austria).

February 4, Replacement of biological methods by chemical and physical methods, London (Chemical Society, Burlington House, London W1V 0BN, UK).

February 5-7, Applied clinical immunology, Houston (The Office of the Director, The University of Texas Health Service Centre at Houston, Division of Continuing Education, P.O. Box 20367, Houston, Texas 77025, USA).

February 11, Techniques for the determination of traces of volatile compounds, London (Chemical Society, Burlington House, London W1V OBN, UK).

February 18, Analysis of pesticides, Chesterford Park (Chemical Society, Burlington House, London W1V 0BN, UK).

February 18, Adhesion of thin films, London (The meetings officer, Institute of Physics, 47 Belgrave Square, London SW1X 8QX, UK).

February 18-19, Contraceptives of the future, London (The Royal Society, 6 Carlton House Terrace, London SW1Y $5 \mathrm{AG}, \mathrm{UK}$ ).

February 26-27, Methods and applications of ranging to artificial satellites and the moon, London (The Royal Society, 6 Carlton House Terrace, London SW1Y 5AG, UK).

6. (a) Twenty Thousand Leagues Under the Sea by Jules Verne; Wells;

(b) The War in the Air by H. G.

(c) The Unparalleled Invasion by Jack London;

(d) The Space Merchants by Frederick Pohl and Cyril Kornbluth.

7. Letters and postcards between Albert Einstein and Willem de Sitter were found at Princeton and Leiden. They discussed the nature of the Universe.

8. In January this year Dr J. D. Isaacs and colleagues suggested that cars driven constantly on one side of the road can create atmospheric vorticity, leading to the formation of tornadoes (see Nature, 253, 254; 1975).

9. When deprived of vitamin $\mathbf{B}_{12}$, some bats develop symptoms of demyelination. They may provide a useful system for research (see Nature, 254, $148 ; 1975$ ).

10. Amphetamine, synthesised in 1927, was first used clinically in 1935 . It produces a state of well being, decreases appetite and increases physical activity.

11. There is an excess of persons born in the first 3 or 4 months of the year in samples of schizophrenic

\section{Reports and publications}

Mammals of the Wankie National Park, Rhodesia By V. J. Wilson (Museum Memoir, No. 5). Pp. 147. (Salisbury: The Trustees of the National Museums and Monuments of Rhodesia, 1975.) [1010 Congress Against the President. Edited by Harvey C. Mansfield, Sr. Pp. 200. (New York: The Academy of Political Science, 1975.) Cyclopoid Copepods (Nanaspididae and Sabelliphilidae) Associated with Holothurians in New Caledonja. By Arthur G. Humes. Pp. iii +41 . Washington, DC: Smithsonian Institute Press, 1975. For sale by US Government Printing Office.) [1010 Publications of the United States Naval Observatory, Second Series. Vol. XXIV, Part 1: Third Catalog of Trigonometric Parallaxes of Faint-Stars. By R. S. Harrington, et al. Pp. 30. (Washington, DC: US Government Printing Office, 1975.) [1010 Smithsonian Contributions to the Earth Sciences. No. 13. Distinctive Properties or Turbiditic and Hemipelagic Mud Layers in the Algéro-Balearic Basin, Western Mediterranean Sea. By Nicolaas A. Rupke and Daniel Jean Stanley. Pp. iil +40 . (Washington, US Gmensonian Institution Press, 1974 . For sale by Uniter States Depting on United States Department of the Interior: Geological Survey. Bulletin 1395-H. Geologic Setting of the Glacier Peak and Mazama Ash-Bed Markers in WestBy R. W. Lemke, M. R. Mudge, Ray E. Wilcox and By R. W. Lemke, M. R. Mudge, Ray E. Wilcox and H. A. Powers. Pp. iii + 31. Professional Paper 877: The Black Hills-Rapid City Flood of June 9-10, 1972: A Description of the Storm and Flood. By Francis $\mathrm{K}$. M. S. Petersen and Donovan B. Kelly. Pp. vi +47 . (Washington, DC: Government Printing Office, 1975.)

Smithsonian Contributions to Zoology, No. ${ }^{1310}$ 206: The Echinoids of Carrie Bow Cay, Belize. By Porter M. Kier. Pp. iii + 45. (Washington, DC: Smithsonian Institution Press, 1975. For sale by US Government Printing Office.)

Theories of Nature and Physics. By Herbert A. Bosch. Pp. 40. (Box 12, Little Falk, Minnesota: Herbert A. Bosch, 1975.)
[1710 United States Department of the Interior: Geological Survey. Water-Supply Paper 2123: Surface Water Supply of the United States, 1966-70. Part 8: Western Gulf of Mexico Basins. Vol. 2: Basins from Lavaca River to Rio Grande. Pp. ix + 861. \$5.70. WaterSupply Paper 2134: Surface Water Supply of the United States, 1966-70. Part 13: Snake River Basin. Pp. ix +821 . \$5.50. Wzter-Supply Paper 2155: Quality of Surface Waters of the United States, 1970. Part 6: Missouri River Basin. Pp. xi + 554. (Washington, DC: Government Printing Office, 1974 and 1975.)

patients. This is called the season-ofbirth effect.

12. In 1665 Philosophical Transactions was founded by Henry Oldenburg, Secretary of the Royal Society.

13. David Davies, editor of Nature, seen through the eyes of daughter Rebecca (see Nature, 254, April 3; 1975, front cover).

14. Charles Wheatstone (see Nature, 256, 532; 1975).

15. Members of the National Astronomy and Ionosphere Center at Cornell University in a message beamed to globular cluster M13, 24,000 light years away. Nature, failing to appreciate the subtleties optimistically aimed at our potential cosmic correspondents, printed the pictorial message the wrong way up. (see Nature, 253, 230; 1975).

16. Most people working on the structure of chromatin (see Nature, 257, 177; 1975).

17. (a) Miguel de Unamuno, The Tragic Sense of Life, page 90;

(b) O. W. Holmes, Medical Essays, page 211;

(c) Plato, Theoetetus, section 1.82;

(d) Adam Smith, The Wealth of Nations, book 5 , part 3 , section 3 . 